\title{
The methodology of the creation of a flowchart of teacher professional development programme in functional literacy aspect
}

\author{
A metodologia de criação de um fluxograma do programa de \\ desenvolvimento profissional de professores no aspecto de \\ alfabetização funcional
}

\section{La metodología de la creación de un diagrama de flujo del programa de desarrollo profesional docente en el aspecto de alfabetización funcional}

\author{
Anna Sukhodimtseva ${ }^{1}$ (D), Marina Sergeeva² iD, Dmitry Lukashenko² iD, Matvey Pyankov² iD \\ ${ }^{1}$ Institute for Educational Development Strategy of the Russian Academy of Education, Moscow, Russia. \\ ${ }^{2}$ Research Institute of the Federal Penitentiary Service of Russia, Moscow, Russia. \\ Corresponding author: \\ Anna Sukhodimtseva \\ Email: suhodimceva@yandex.ru

\begin{abstract}
How to cite: Sukhodimtseva, A., Sergeeva, M., Lukashenko, D., \& Pyankov, M. (2021). The methodology of the creation of a flowchart of teacher professional development programme in functional literacy aspect. Revista Tempos
\end{abstract} \\ e Espaços em Educação, 14(33), e15525. http://dx.doi.org/10.20952/revtee.v14i33.15525
}

\begin{abstract}
The study has been directed to the teacher professional development perfection problem in functional literacy aspect as an integral part of holistic educational process to increase student efficiency, in compliance with the OECD's Programme for International Student Assessment. The purpose is to research the historical content of the functional literacy phenomenon and approaches to a programme flowchart for teacher professional development education. A flowchart of the programme of teacher professional development has been elaborated to create an e-platform to enable teachers to master a competence-based model for further teaching and projecting educational process to form relevant functional literacy of students.
\end{abstract}

Keywords: Algorithm. Bibliometrics. Course. Education. Modernization.

\section{RESUMO}

O estudo foi direcionado ao problema de aperfeiçoamento do desenvolvimento profissional do professor no aspecto de alfabetização funcional como parte integrante do processo educacional holístico para aumentar a eficiência do aluno, em conformidade com o Programa da OCDE para Avaliação Internacional de Alunos. O objetivo é pesquisar o conteúdo histórico do fenômeno da alfabetização funcional e as abordagens de um fluxograma de programa para a formação profissional de professores. Um fluxograma do programa de desenvolvimento profissional de 
professores foi elaborado para criar uma plataforma eletrônica para permitir que os professores dominem um modelo baseado em competências para continuar o ensino e projetar o processo educacional para formar uma alfabetização funcional relevante dos alunos.

Palavras-chave: Algoritmo. Bibliometria. Curso. Educação. Modernização.

\section{RESUMEN}

El estudio se ha dirigido al problema de la perfección del desarrollo profesional docente en el aspecto de la alfabetización funcional como parte integral del proceso educativo holístico para aumentar la eficiencia de los estudiantes, de conformidad con el Programa de la OCDE para la Evaluación Internacional de Estudiantes. El propósito es investigar el contenido histórico del fenómeno de la alfabetización funcional y los enfoques de un diagrama de flujo del programa para la formación del desarrollo profesional docente. Se ha elaborado un diagrama de flujo del programa de desarrollo profesional docente para crear una plataforma electrónica que permita a los docentes dominar un modelo basado en competencias para seguir enseñando y proyectar el proceso educativo para formar una alfabetización funcional relevante de los estudiantes.

Palabras clave: Algoritmo. Bibliometría. Curso. Educación. Modernización.

\section{INTRODUCTION}

The global challenge of knowledge economy and information society development embraces new techno-economic paradigm, introduction of revolutionary inventions of quantum computers, blockchain, virtual reality, artificial intellect, platforms and has attached a leading role to world education system. The Russian education is now being reoriented to train teachers creating such qualities as independence and efficiency of using knowledge in an uncertain situation, making conscientious choice and forecasting the consequences of its development, obtaining personal qualities of a responsible active citizen and ability to cooperate.

The relevant context directly highlights the content of functional literacy defined as an indicator of a developed society and high quality education. "That is the reason for the concept of functional literacy to be regarded as a measurement tool for the evaluation of the quality of life in a society and cultural standard" (Rudik et al., 2014, p. 263). Both academic disciplinary/interdisciplinary knowledge and functional literacy have become the main focus of the Russian education system nowadays.

The study has stated the problem to elaborate theoretical methodological basis for a flowchart as a key engine of programmes of teacher professional development in functional literacy aspect aiming at actual practical advancement of the entire system.

The formation and assessment of student functional literacy aged 15 is determined in the framework of the international study of PISA (Programme for International Student Assessment) coordinated by the Organization for Economic Co-operation and Development (OECD, n.d). The Russia-based PISA studies are located at the Federal State Budgetary Scientific Organization "Institute for Strategy of Education Development of the Russian Academy of Education" (hereinafter referred to as "Institute for Strategy of Education Development"). The Institute is a leading federal Department effecting long-term education development policy, Centre for the education quality assessment of the general education including the PISA comparisons and also the UNESCO member.

The components of the functional literacy content in the PISA study include mathematical, reading, natural science, financial types of literacy and global competence (OECD, 2019). Student global competence has been studied recently and methodological manuals for schools have been elaborated only in the past two years (Rudik et al., 2014; Koval \& Dyukova, 2019a, 2019b).

We give a brief analysis of the teacher professional functional literacy background. The PISA comparative research results have shown the success of Russian school students in their disciplinary knowledge. However, students do not know how to use knowledge in unfamiliar situations close to 
life (Basyuk \& Kovaleva, 2019). These facts are proved by the articles of 2010 "We have failed again in the PISA format" (Pentin, 2010, p. 11) and 2018 "Education in the Russian school is concentrated rather on the acquisition and demonstration of knowledge than on its application"(Pentin et al., 2018, p. 82), which "does not contribute to the formation of student competencies such as cognitive initiative, risk of choice, persistence in the implementation of cognitive interest and novelty" (Volkova et al., 2019, p. 987).

The main drawback to the Russian education system lies in the following facts. This is a lack of teacher professional competences in functional literacy who have been guided by traditional teaching principles due to predominant experience working within the framework of "knowledgebased education" paradigm. In fact, at the beginning of 2018/2019 academic year a quarter of Russian teachers of state educational institutions were at the age of 55-65 (Ministry of Education of the Russian Federation, 2019). As a result, many teachers

[...] cannot effectively solve the problem of forming relevant functional literacy of students, which requires operating such concepts as uncertainty, ambiguity, divergence, insufficient reliability of information, the presence of alternative points of view, the need to transfer from the everyday situation to its mathematical or natural science models (Bakhareva, 2009, p. 54).

Moreover, $65 \%$ of teachers of this age group have only partially accepted innovations related to the introduction of the new Federal State Educational Standards (Russia), and functional literacy stipulated by it (Shaikhelislamov, 2019). The situation has not been changed by the scientific methodological literature for teachers which has appeared recently in the educational market (Kovaleva et al., 2020c, 2020e; Sergeeva, 2020).

Researchers have stated the need to optimize this process by solving, firstly, strategic fundamental problems related to the continuity principle of education at the level of primary and basic schools (general education): the content of the main disciplines studied at primary and basic general schools is not built in a holistic logic. Primary school teachers don't practically cooperate with teachers working at the basic general education level (Kovaleva, 2017). Secondly, the problems of disciplinary-based training courses related to the presentation of material in the course textbooks, which leads to insufficient mastering of some mandatory disciplinary material by students. This circumstance has negatively affected the results of performing the PISA tasks (Roslova et al., 2019). Thirdly, problems of teacher professional development system are focused on mainly disciplinary basis. The content of the programmes is narrow and does not concern the issue of the methodology of teacher activity, its modernization in the new conditions.

\section{LITERATURE REVIEW}

The functional literacy problems, i.e. its social significance, content, purpose, formation models, have been recorded in educational documents since the 50s of the 20th century. It is important to note the opinion of Sharon Feiman-Nemser, a professor at the University of Michigan (USA), the founder of the innovative pedagogical educational programme. The research has confirmed the thesis that the educational levels of teachers and their students are closely interrelated (Feiman-Nemser \& Norman, 2000). In Russia the content of modernization in education system has been defined as innovative educational practice particularly in the context of functional literacy (Osmolovskaya et al., 2019).

In modern Russia the phenomenon of functional literacy has been studied since 1990 at an advanced stage. Since 2018 "Institute for Strategy of Education Development" has been implementing an innovative thematic project of the Ministry of Education of the Russian Federation "The monitoring of functional literacy formation". One of the plans is to "develop a system of tasks for students in 5-9 grades grounded on a system-activity-based approach". New educational 
methodological materials are focused on the development of positive personal attitudes, motivation for learning and strategies of students' behavior in various situations (Basyuk \& Kovaleva, 2019).

The literature describes the dynamic and multi-aspect nature of functional literacy phenomenon related to spatial and temporal changes. Thus, V.A. Ermolenko (2015) has established four stages of development of functional literacy concept: 1) at the beginning of the 20th century functional literacy was considered as a supplement to the traditional one; 2 ) at the middle of the 20th century the society started to deeper understand a phenomenon of social variability. Functional literacy began to separate from the traditional one; 3 ) by the end of the 20th century traditional literacy had been already included in the functional literacy. It was thought to have twolevel structure (global and regional) and regarded as the basis of lifelong education; 4) at the beginning of the 21st century the significance of functional literacy as the basis for personal success in a changing world has been emphasized.

In its essence, the functional literacy acquisition is close to the understanding of social competence the structure of which "develops in the context of social reality" (Sergeeva et al., 2017, p. 84). In practice knowledge-based concept approach still prevails at schools. It has been proved by the results of the Federal Russian Competition "The teacher of the year" (2018), as well as 240 summaries of teachers' classes planning from 33 regions of Russia, available on professional websites. Almost $50 \%$ of children have not been included in effective classroom educational activities because the teacher uses unproductive techniques (Sukhodimtseva et al., 2018b; 2020).

A review of the methodological literature on the theme of teacher professional development has shown a lack of multi-faceted approaches to courses in the system of supplementary teacher professional education (Info-lesson, n.d).

The publications of the Volga interregional center for teacher professional development at Kazan Federal University (Tatarstan region) have proved that from $27.6 \%$ to $62.2 \%$ of teachers need methodological assistance, especially in setting goals and evaluating the school students' educational achievement (Shaikhelislamov, 2019). Due to the fact that 1073 professionals of numerous Russian regions have participated in research, its results and conclusion can be extrapolated and interpreted to the system of the Russian general education.

The results of the 2018 Teaching and Learning International Survey (TALIS) International study stated "Russian teachers, in general, are ready to learn in practice as well as to learn collectively from each other" (TALIS, 2018). Research publications of Bakhareva (2009) describe the cluster approach as the basis for such training.

Foreign researchers also emphasize the effectiveness of joint project training, which "contributes to the motivation to strive for professional excellence" (Collie \& Martin, 2017, p. 199). For example, Slavin (2011) and Adams (2013) note that today cooperative learning concept is considered as one of the methods to combine the opportunities of participants in the educational process. Such practices, according to foreign scientists (Bellisario \& Donovan, 2012), is a primary factor of education, since they motivate students to learn and develop life experience. Van Doorn \& Eklund (2013) has emphasized the process of communication and interaction as a prerequisite for a person's cognitive development.

Scientists from Kazakhstan analyze the process of teacher development in the system of supplementary professional education grounded on a competence-based approach. The program "The development of functional literacy (reading, mathematical, natural science) of students in the context of the PISA study has been designed and implemented. The main focus is on transition from "knowledge-centered learning paradigm to competence-based and reflexive analysis of activities" so that teachers could "test their skills in classroom practice and extracurricular independent work" (Sabieva \& Bulatova, 2017, p. 121). 
Innovative forms of independent work have been introduced: workshops (opinions exchange in the context of preparing team projects), a collective elaboration of class material fragments, etc. Teachers unite on an interdisciplinary basis, integrating efforts and solving problems in its complexity. At the end of the course pedagogical projects (programmes, models) are to be defended as graduation work. In a similar situation in the UK the case study research method is often used. The book by Arch Woodside (2010) highlights the theory, methods and practice of case study research, provides positional schemes of the course participants and based on a fixed real behavioral model offers the role for each person at a certain time. This is important for identifying individual content in the collective activities of a team of teachers in the context of course training and developing their active position.

The publications of the specialists from Omsk Academy of lifelong education (Gam \& Mikhailova, 2018) have specified the following relevant forms of teacher professional development: a) distance learning based on a website or a web page, which content is filled by the participants; b) personalized form of professional development as a holistic system of three interrelated types of training: individualized, inter-individualized and meta-individualized ones; c) e-learning is a hypertext structure that combines media resources (hypermedia, electronic textbooks, video materials); d) modular form of training: block-modular principle of programmes; e) project form of training: project content and project activity "development of project consciousness and selfawareness of a teacher, introduction of project activity concepts, its terms and definitions into its structure" (Krasnov et al., 2019); f) network form of training: modernization of teachers' network communities' activities and support of the learning process; $g$ ) the format of a probation: individual assignments, research work, solution of start-to-finish professional tasks, business and situational games.

An important aspect regarding the development of teachers' professionalism concerns the motivational aspect. A large number of teachers register for distance courses, but less than a third of them accomplish the goal. Foreign scientists offer a number of approaches to solve this problem. Thus, the works by R. Low and P. Jin (2009) "Motivation and multimedia learning", the model by Keller and Suzuki (2004) "Attention-Relvance-Confidence-Satisfaction" (ARCS), the model of "Selfdetermination" (STD) by Legault (2017), Sergis (2018), the model of "Social cognitive learning" (SLT) by Bozack (2011) have been implemented.

The first model of ARCS (attention-relevance-confidence-satisfaction) is aimed not at controlling in the conditions of distance learning, but at maintaining the motivation of the student through, for instance, various bonuses in the form of a score calculation system, incentives to achieve the learning goal (Law et al., 2019). It is significant to make an input of such parameters into the electronic system, in the training program. Russian science analyses this problem in the context of interaction between the categories of intellect and technology (Pluzhnikova et al., 2018).

The second model of STD (self-determination theory) is aimed at working in the individual field of a student and encourages personal and professional growth, self-control. Scientist Yilmaz (2017) use the following scales of readiness for e-learning in the electronic programme: "computer self-efficacy", "Internet self-efficacy", "the efficacy of online communication", "self-directed learning", "student control" and "motivation towards e-learning", satisfaction scale and the motivated strategies for learning questionnaire. In Russian science this approach is characterized in the wording "a teacher's self-effectiveness" as a component of professional stability of teachers (the ability to effectively act in a situation of uncertainty) (Savchenkov, 2019).

The third model is SLT (social learning theory). Albert Bandura's social cognitive theory conceptualizes cognitive, mediated, self-regulating, and self-reflexive processes in their relation to human motivation and behavior (Cit. by Bozack, 2011).

The publications studied have indicated great social demand for the further modernization of education and creation of the holistic educational system. The research works have developed a 
certain context for the elaboration of conceptual approaches to develop an integrated system of educational process for the formation of a modern level of functional literacy of students and teachers in advanced educational courses.

\section{METHODOLOGY}

The research has been conducted in the context of the factor, interdisciplinary/integrative, bibliometric/scientometric, project-technological/ competence-based methodological approaches.

The methods of bibliometric / scientometric approach (Hood \& Wilson, 2001), such as statistical analysis, content analysis, thesaurus analysis, have allowed establishing information and scientific content on the research problem, its thematic field and the dynamics of the functional literacy phenomenon development in Russian scientific methodological publications, defining the interest of researchers from various scientific fields exactly in the theme of functional literacy and in the Federal Project of the Ministry of Education of the Russian Federation "The monitoring of the functional literacy formation" with the substantial contribution of "The Institute of Strategy of Education Development" to it.

This has allowed identifying steady academic networking and the priority research areas within the Federal Project with the aim of establishing the degree of development of the scientific problem of teacher professional development in the Project.

Hence, we have studied the collections of the electronic funds of the Russian State Library, which amount to about 1.5 million titles. There have been disclosed 77328 relevant publications within the time period of 1995-2020. The first publications came out in the late 90s of the 20th century, high intensity of relevant publication activity is related to the first fifteen years of the 21st century. The monographs, dissertations, scientific journals covered the theoretical aspects of the problem from the positions of Russian and foreign scientists, the first practical educational methodological manuals started to come out in the beginning. At present research-to-practice conferences have also been intensively held.

Thus, the dynamics of functional literacy phenomenon development in the Russian scientific and methodological publications has been defined by the authors (Figure 1).

The methodology of project-technological approach has permitted judging the problem of teacher professional development in the project category as a normative model of some system and as a purposeful amendment of a system limited in time and resources and having a specific organization (according to Novikov \& Novikov, 2009).

The methodology of the factor approach has allowed identifying motivations for the teacher professionalism development in the formation of school student functional literacy and take them into account designing a flowchart of the programme for the system of supplementary teacher professional education: personal and educational needs of teachers regarding the professional activity problems.

The researchers Gam \& Mikhailova (2018) also note the following factors: a) organizational conditions: variety and quality of programmes (content blocks and modules), a wide range of forms of training, a differentiated approach; b) resource factors: modern educational materials, library stock, computer and ICT facilities, including interactive whiteboards, Smart technologies, distance learning; c) activity-based nature of training: practicing the acquired knowledge; using effective forms in the learning process, stimulating the active position of the student.

The methodology of the interdisciplinary / integrative approach has permitted establishing the integrated nature of the functional literacy and giving grounds for implementing organizational forms and tools in the supplementary teacher professional education. It has also allowed us to highlight "interdisciplinary integration as a way to actualize the content of modern education" (Korosteleva et al., 2019). 
Figure 1. Dynamics of publications on the problem of functional literacy.

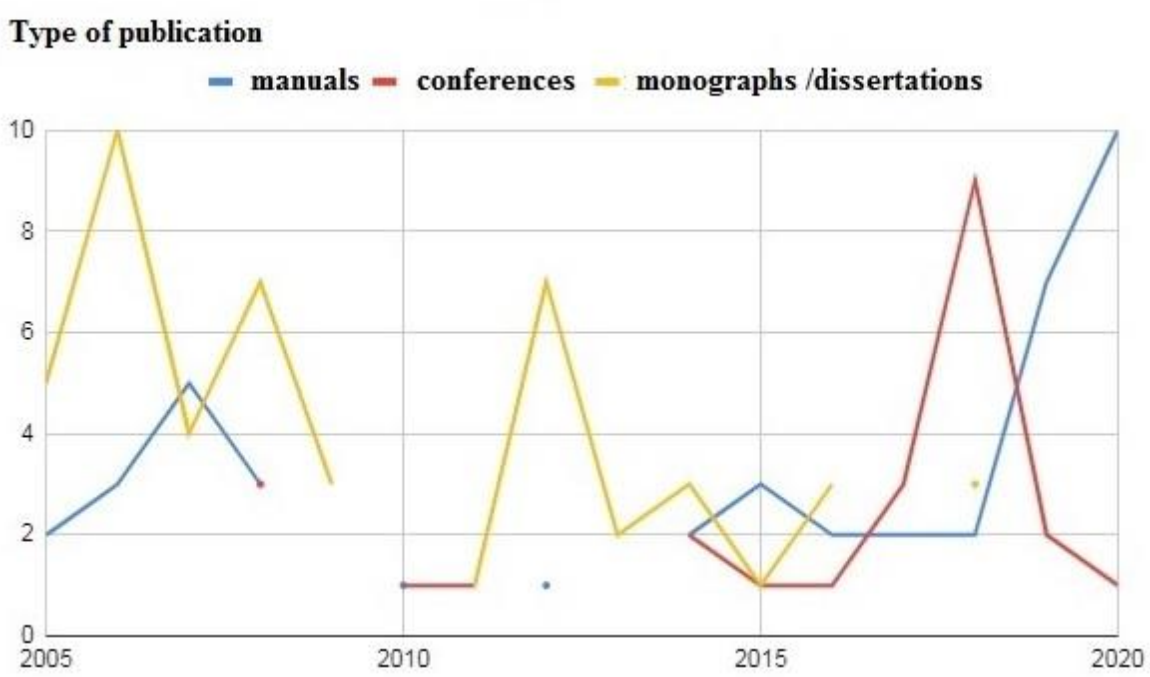

\section{RESULTS}

Since 1990 Russian professionals of different disciplines (sociologists, philologers, economists, Culture and Arts researchers) have been performing numerous studies the subjectmatters of which are various aspects of functional literacy formation of students at all levels of education system. Our research has clearly revealed that at the present stage the scientific and practical problem of advanced modernization of teacher professional education with the aim of developing holistic system of educational process has not been thoroughly researched and understood.

Our research results have allowed specifying the actuality of the above problem and suggesting one of the methods to solve it.

The researchers have presented a macro (non-detailed) flowchart of a programme of teacher professional development of the relevant level of functional literacy aspect for a website of an institution of teacher professional education. (Figure 2). The conceptual framework of the programme is grounded on competence-based, factor, project-technological and interdisciplinaryintegrative methodological approaches. The programme can be used in all of forms of teacher professional education and acquire a status of lifelong education.

The aim of the flowchart is to elaborate methodology that allows for teachers to come to deep understanding how they will be further modernizing their real educational practices. We regard modernization as a process of analyzing pedagogical principles and progressively changing educational organizational conditions and facilities.

The description of the flowchart. The flowchart has been built according to "The cycle with post-condition" algorithm, which presupposes that the method of outperforming advanced activitybased development of the programme material with the subsequent reflection has been implemented.

The programme has a block-modular content base. A module is a completed cycle of a separate theoretical or practical part of the programme with the subsequent module information reflection in the form of a "test". The category of reflection includes "the ability of a person to mentally depart from the subjective viewpoint, looking at oneself through the eyes of other people" (Novikov, 2011, p. 131). So, in the "Module Cycle" structure the operation is repeated until the "test" requirements have been fulfilled.

Within the framework of the paper the format of mastering and acquisition of the material in this flowchart has not been presented as an algorithm. 
However, each module is supposed to have a unified media resource, hyperlinks to reference books and dictionaries, presentations in online mode, recordings in digital formats, video materials, simulators on a specific topic of the module. It is possible to branch out into different kinds of educational material.

Classes in the distance learning include web quests, teleconferences, virtual discussions, situational analysis. Teachers use information technologies: info-graphics, scribing, mind mapping, sketch, storytelling, timeline charts.

Figure 2. The Flowchart of the Programme.

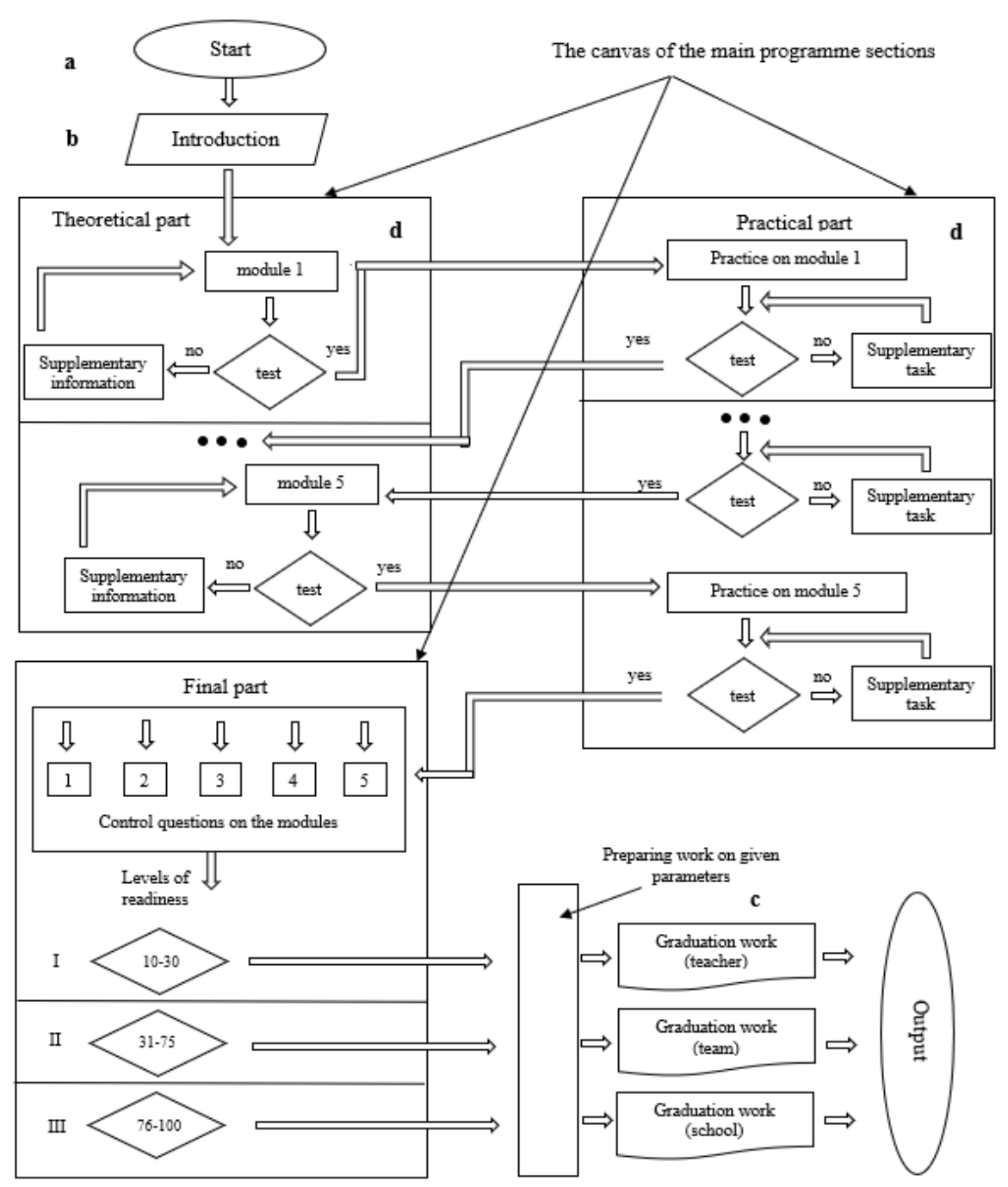

Notes: Oval (a) is the beginning and the end of the cycle. Parallelogram (b) is a data entry. Arrows are flow lines, i.e. the sequence of communication between the cycle components in the module and during the course. A quadrilateral with a broken line (c) is the printing of the document. Symbols in the web of the programme main sections: The canvas of "Module Cycle" is (d). Quadrilateral is the process of mastering the module material. Rhombus is for the reflection test. The marks of omission (for the sake of the scheme brevity in the paper) is the place of cycles of modules 2-4, similar to module 1 and module 5.

We should illustrate the above information with module 1 as a fragment of the process flowchart. Figure 3 shows the possible content of the module and the scenario for working with it. 
Figure 3. Conditional content of module 1.

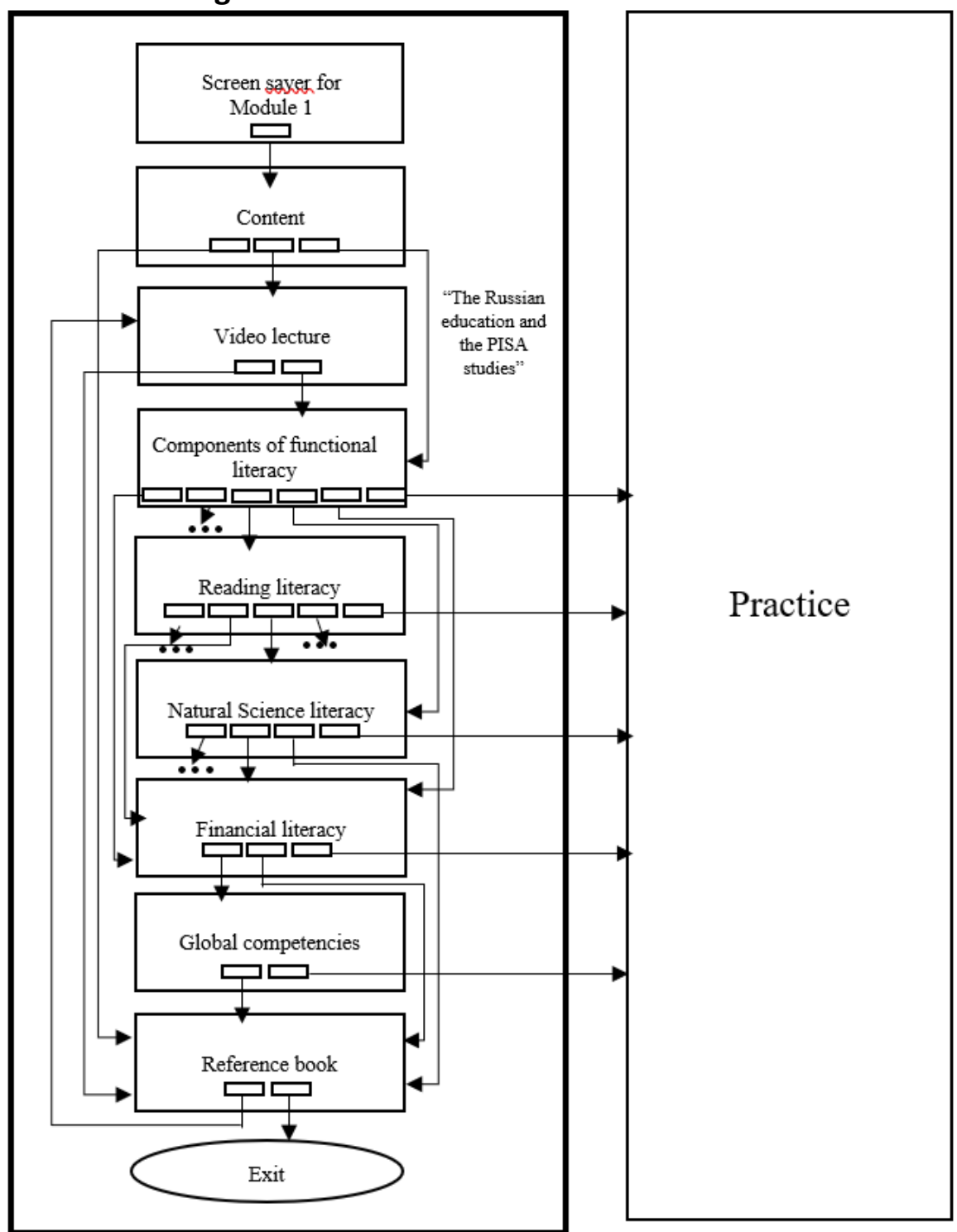

Notes: Oval is the beginning and the end of the cycle. Arrows are flow lines, i.e. the sequence of communication between the circle components in the module. A large quadrilateral is a frame in the flowchart of the module system. A small quadrilateral is the button for moving to the next frame, i.e. the navigation control command in the module. The ellipsis indicates that the content is fragmented.

Two-level integration has been provided: external integration as interdisciplinary material processing and internal integration of all the studied sections of the course. Integration/Interdisciplinarity presupposes "convergence and reciprocal influence of disciplines in any training session" (Gam \& Mikhailova, 2018, p. 119).

It has been planned to integrate various forms of training (individual and group, educational and scientific research, etc.). The practical part of the module involves performing tasks on a disciplinary and interdisciplinary basis (Sukhodimtseva et al., 2018a) with the orientation towards the characteristics of functional literacy aspects. Both in Russian and foreign science the integrative approach is one of the most effective for the productive organization of student education (Klein, 2017; Sergis, 2018).The practical part of the module presupposes task accomplishment on both disciplinary and interdisciplinary basis (Sukhodimtseva et al., 2018a).

At the final part of the programme (Figure 2 ) teachers are given a test for self-control of the level of cognitive content assimilation and acquisition of various competencies: creating an author's 
products, ability to plan one's own activities at the end of the course, pedagogical interaction at the level of cooperation, etc.

Accomplishing final integrated tasks allows ranking an individual teacher's progress by levels (I-III) at the end of the course based on the points received by teachers (from 10 to 100). That is the method of implementing diagnostic assessment, which "is a good tool for determining the level of education" (Bolotov et al., 2015, p. 535). "The evaluation system should be aimed at its practical implementation, i.e. evaluation is necessary for making judgments about the object and improving its effectiveness" (Varkulevich et al., 2018, p. 31).

Depending on the results of score calculation on the final test, teachers are to perform their final graduation work by doing either an individual project or acting as a participant of a group or network project. Teachers must thoroughly understand the methodology of education process organization. Thus, teachers must perfectly understand the modernization methods of real educational process. With the purpose to contribute to teacher professional development, the authors of the study have elaborated two project approaches. The first approach to school modernization embraces the following. A teacher is to project an amendment in the educational situation based on the approach "from the general to the specific". The interdisciplinary/disciplinary results of the educational course are designed with respect to functional literacy, taking into account the students' achievement of interdisciplinary results necessary for solving the PISA tasks, for example, such skills as working with information presented in various forms (text, tables, graphics) or obtaining information that is not directly contained in the task when it is required to use household data, personal life experience, etc.

With this in mind, the educational objectives are to be specified in the planned learning results at the end of each year, term, and module topic. Teachers working on such project basis identify cross-cutting disciplinary/interdisciplinary lines of the educational course concerning functional literacy.

The second approach to modernization of education process is "from the specific to the general". In this case, the didactic objective is to be specified in the planned results of each stage of the lesson. The interdisciplinary content of other disciplines is taken into consideration with the orientation to the planned results of the topic of the module. For example, it is possible to plan systematic testing of interdisciplinary skill of self-control over fulfillment of conditions (constraints) in finding solutions and interpreting results in the context and assessing its level at the end of the lesson. In case of working within the discipline material on the formation of, for instance, mathematical literacy, teachers need to take into account the results of research received in the framework of the above-mentioned Federal Project.

The specialist have focused a number of skills worth paying careful attention to. For example, the programme of the 5th year includes skills to be able to perform operations with natural numbers, ordinary fractions, and the programme of the 7th year embraces all kinds of activities stipulated for the 5 th year.

In addition, it is necessary to use the materials of textbooks for school students of the new series (2020): collections of reference tasks: "Natural Science literacy", "Global competencies", "Creative thinking", "Mathematical literacy", "Financial literacy", "Reading literacy" (Kovaleva et al., 2020a, 2020b, 2020c, 2020d, 2020e, 2020f).

Thus, at the end of the course teachers must present a classroom project of the integral process of forming student functional literacy, either within the module topic, or within the entire course of the discipline, or at the section level of a school educational programme, etc. It is significant for teachers to clearly realize the purpose and the means for the innovative educational processes to be carried out as well as the assessment tools for determining its effectiveness, efficiency and quality. 


\section{DISCUSSION}

One of the challenging tasks of the strategy of the federal education system development is to find optimal solution to the actual urgent problem of teacher professional development, which will enable teachers to design new level of classes, to fully comprehend significance and priority of functional literacy problem in order to be able to create holistic thematic planning on an interdisciplinary basis in accordance with the requirements of both the federal state standards and the international PISA studies. Exploring the philosophy and content of the PISA research, we have carefully considered a number of practical examples of recent relevant methodological and organizational experience in Russian education in the context of the methodology of a flowchart creation of teacher professional development in functional literacy aspect. In this context practical manuals on teacher professional development are extremely important as software and methodological tools.

Samara Regional Institute for teacher professional development has decided to "elaborate and implement a special course which task is to advance functional literacy in the educational process of each Russian school" (Panarina et al., 2019, p. 38). Functional literacy is appreciated as the goal, value and result of basic general education. In 2019 its specialists prepared the manual "The development of functional literacy of basic general school students: a methodological guide for teachers" designed for the preparation and conduct of training sessions aimed at the development of functional literacy of students in grades 5-9. It describes the content of a specialized module course. Particular attention is paid to the didactic and methodological tools for the arrangement of students' cognitive activity providing all components of student functional literacy development (reading, mathematical, natural science and financial types). The manual authors have explored the history of the development of functional literacy phenomenon not only from the position of the activity context, but also analyzed the knowledge component of the educational system, or functional knowledge, according to the definition proved in the study of Ermolenko (2015). Based on the works of the Russian researchers (Rudik et al., 2014), the authors of the manual cite the distinctive features of functional literacy.

According to the PISA context, we should employ an approach according to which functional literacy is understood in a broad sense as a set of knowledge and skills of citizens providing for the successful socio-economic development of the country. In a narrow sense, it is a key knowledge and skills necessary for a citizen's fully-fledged participation in a modern society (OECD, 2019).

So, the manual contains a full description of the course programme for students, which is valuable for the practical part of the flowchart of the programme presented above in this paper, but it is lacking in the PISA global competences for students.

In this regard we should refer to the manual "Global competencies: a collection of reference tasks" developed by the scientific staff of "The Institute for Strategy of Education Development of the Russian Academy of Education" (Kovaleva et al., 2020a).

The structure of the manual encompasses a description of general approaches to knowledge and skills evaluation, testing and assessment materials. The manual consists of two parts: the first part gives an example of a training task, the second one offers tasks for student independent work and answers to tasks formulated as a basis for self-testing. In 2018 the staff of the Institute elaborated a teacher professional development programme "The system of evaluating school students' educational achievements as a mechanism for enhancing general education quality" (Kovaleva, 2018).

The programme consists of the following basic and profile components. The basic part has two subsections. The first subsection covers the Russian Federal State Educational Standards in the system of legal and regulatory basis as well as methodological support of educational organizations. The second subsection is devoted to the problem of the place of Russian education and its significance in the international comparative studies. 
The profile (disciplinary-methodological) part contains themes revealing the model for evaluating educational achievements in accordance with the Federal State Educational Standards of general education, the assessment of meta-subjective and personal results, intra-school control as a mechanism for practically improving education quality, and the methodology for designing competence-oriented tasks. The course ends with the completion of project work. In fact, the course is lacking in addressing the relevant issues of modernization of teacher activities in the context of functional literacy.

The State Budgetary Educational Institution of supplementary teacher professional education "The Institute of education development of Omsk region" (Orlova et al., 2019) offers another teacher professional development programme. It has proposed an approach to creating factual practice tasks with the use of task expertise to assess the student functional literacy. However, attending professional development courses teachers are not inclined to demonstrate their competence as experts in the programme development or student competence acquisition assessment. Teachers do not always tend to complete professional development courses. Such trends have also been fixed abroad. For instance, teachers tend to avoid doing courses for different reasons in the Federal Republic of Germany (Feiman-Nemser \& Norman, 2000). Although we should point out it is known in developed countries teacher professional development programmes are rich and multi-faceted, especially in the sphere of ICT technologies (Chiout, 1982). The USA scientists advise the programmes should include a continuous process based on real observations, solving problems of "practice in high quality professional contexts" (Feiman-Nemser \& Norman, 2000, p. 732).

The main thesis of the study is as follows. The present research has revealed a substantial lack in full understanding of the strategic fundamental systemic problem of education: the category of holistic educational process still remains outside the focus of the professionals both in Russia and abroad.

\section{CONCLUSION}

The present study has explored the thematic context, background of functional literacy development in Russian Pedagogy and in the modern condition of transition from the knowledgebased paradigm to the competence-based model has actualized the problem of modernization of teacher professional activity in compliance with the PISA requirements.

The conclusions are as follows:

1. The research has presented the methodology of the creation of a flowchart of a teacher professional development innovative programme in functional literacy aspect and has regarded it as a key component to solve the challenging task of the education system advanced development and the conditions for its competitiveness in the world.

2. At the present stage of the information society development functional literacy has generated greater interdisciplinary political, cultural, socio-economic, technological, pedagogical interest and has required new advanced scientific methodological and practical approaches. This is characteristic of both the Russian and foreign scientific communities and educational practitioners.

3. The study has highlighted the strategic requirement for Russian school students to achieve higher levels of functional literacy acquisition to comply with the PISA directives. The conditions should be provided to enable students to compete with their foreign peers participating in the international PISA studies on an equal footing.

4. The actual problem of lifelong teacher professional competence development must be solved on a comprehensive basis. It is critically and strategically important that teachers should regard the educational process as a complete holistic system. The flowchart of a programme of teacher professional education designed by the authors has been offered as technological and content methodological fundamentals to practically solve the problem stated in the present study. 
The conceptual approaches for elaborating the flowchart of the teacher professional development programme have allowed creating scientific methodological basis for teachers to master the necessary competencies for designing/modeling/modernizing their professional activities as regards to the requirements of the Russian federal educational standards and international PISA study for the educational results of school students.

The description of the study has not included the analysis of the substance of the educational processes in their whole entirety and completeness concerning the methodology of the flowchart of the programme of teacher professional education. Since the designing/modeling/modernization of the programme based on the flowchart is meant for further development in blockchain system, the authors of the present study continue to conduct next stages of the research work on interdisciplinary basis aiming at contributing to the deed of a holistic educational process, promoting scientific and practical methodological foundation and advanced educational practice.

Authors' Contributions: Sukhodimtseva, A.: conception and design, acquisition of data, analysis and interpretation of data, drafting the article, critical review of important intellectual content; Sergeeva, M.: conception and design, acquisition of data, analysis and interpretation of data, drafting the article, critical review of important intellectual content; Lukashenko, D.: conception and design, acquisition of data, analysis and interpretation of data, drafting the article, critical review of important intellectual content; Pyankov, M.: conception and design, acquisition of data, analysis and interpretation of data, drafting the article, critical review of important intellectual content. All authors have read and approved the final version of the manuscript

Ethics Approval: Not applicable.

Acknowledgments: The paper has been prepared within the framework of the state task No. 073-00007-20-01. The publication has been prepared with the support of "RUDN University Program 5-100"..

\section{REFERENCES}

Adams, A. (2013). Cooperative learning effects on the classroom. Northern Michigan University.

Bakhareva, E. V. (2009). Improving the teachers' professional competence in the development of secondary school students' functional literacy. Science and school, 2, 54-55.

Basyuk, V. S., \& Kovaleva, G. S. (2019). Innovative project of the Ministry of Education "Monitoring the formation of functional literacy": main directions and first results. Domestic and foreign pedagogy, 61(4), 13-33.

Bellisario, K., \& Donovan, L. (2012). Voices from the field: Teachers' views on the relevance of arts integration. Cambridge, MA: Lesley University. Available: https://www.artsedsearch.org/study/voices-from-the-field-teachersviews-on-the-relevance-of-arts-integration

Bolotov, V., Valdman, I., Kovaleva, G., \& Pinskaya, M. (2015). Russian quality assessment system in education. Russian Education and Society, 57(7), 531-571. https://doi.org/10.1080/10609393.2015.1096145

Bozack, A. (2011). Social Cognitive Learning Theory. In: Goldstein, S., Naglieri, J. A. (Eds.). Encyclopedia of Child Behavior and Development. Boston, MA: Springer. https://doi.org/10.1007/978-0-387-79061-9 2715

Brito, R. S., Prado, J. R., \& Nunes, C. P. (2017). As condições de trabalho docente e o pós-estado de bem-estar social. Revista Tempos e Espaços em Educação, 10(23), 165-174. https://doi.org/10.20952/revtee.v10i23.6676

Chiout, H. (1982). Lehrerfortbildung in England, Schweden und Dänemark: Versuch eines Vergleichs. Zeitschrift für Pädagogik, 6, 911-934.

Collie, R. J., \& Martin, A. J. (2017). Adaptive and maladaptive work-related motivation among teachers: a personcentered examination and links with well-being. Teaching and Teacher Education, 64, 199-210.

http://dx.doi.org/10.1016/j.tate.2017.02.010

Ermolenko, V. A. (2015). Development of the student's functional literacy: theoretical aspect. Space and time, 8(1), 2.

Feiman-Nemser, S., \& Norman, P. J. (2000). Teacher education: From initial preparation to continuing professional development. In: Moon, B., Ben-Peretz, M., Brown, S. A. (Eds.). Routledge international companion to education. New York, NY: Routledge, pp. 732-755. 
Gam, V. I., \& Mikhailova, V. E. (2018). Modern forms of teachers' professional development organization. Russian Journal of Education and Psychology, 9(1), 119-133. Available: http://journal-s.org/index.php/sisp/article/view/10606

Hood, W. W., \& Wilson, C. S. (2001). The Literature of Bibliometrics, Scientometrics, and Informetrics. Scientometrics, 52(2), 291-314. https://doi.org/10.1023/A:1017919924342

Info-lesson. (n.d). Course program "Schoolchildren's functional literacy". Available: https://infourok.ru/kursy/funkcionalnaya-gramotnost-shkolnikov/

Keller, J. M., \& Suzuki, K. (2004). Learner motivation and E-learning design: a multinationally validated process. Journal of Educational Media, 29(3), 229-239. https://doi.org/10.1080/1358165042000283084

Klein, J. T. (2017). Typologies of Interdisciplinarity: The Boundary Work of Definition. In: Frodeman, R., Klein, J. T., Pacheco, R. C. S. (Eds.). The Oxford Handbook of Interdisciplinarity, 2nd edn. Oxford: Oxford University Press.

Korosteleva, A. A., Kryuchkova, E. A., Zharkovskaya, T. G., Basik, N. Y., \& Romanova, M. Yu. (2019). Interdisciplinary integration as a way to update modern education content. In: The European Proceedings of Social \& Behavioural Sciences. International Conference "Education Environment for the Information Age" (EEIA 2019), June 4-5, 2019, Moscow, Russia. Future Academy, pp. 450-458. https://doi.org/10.15405/epsbs.2019.09.02.52

Koval, T. V., \& Dyukova, S. E. (2019a). Global competencies - a new component of functional literacy. Domestic and foreign pedagogy, 4(61), 112-123.

Koval, T. V., \& Dyukova, S. E. (2019b). How to evaluate students' skills in the sphere of global competencies. Domestic and foreign pedagogy, 4(61), 208-217.

Kovaleva, G. S. (2017). New tasks that monitoring research results put before science. Domestic and foreign pedagogy, 2(38), 153-163.

Kovaleva, G. S. (2018). Program of additional professional education (advanced training) "System of schoolchildren's educational achievements assessment as a mechanism for improving the quality of general education". Domestic and foreign pedagogy, 1(4), 152-170.

Kovaleva, G. S., Koval, T. V., \& Dyukova, S. E. (2020a). Global competencies. Collection of reference tasks, 1st edn. St. Petersburg; Moscow: Prosvetshchenie.

Kovaleva, G. S., Loginova, O. B., Avdeenko, N. A., \& Yakovleva, S. G. (2020b). Creative thinking: a collection of reference tasks: a textbook for general education organizations. St. Petersburg; Moscow: Prosveshchenie.

Kovaleva, G. S., Pentin, A. Yu., Nikishova, E. A., \& Nikiforov, G. G. (2020c). Natural and scientific literacy: a collection of reference tasks: a textbook for general education organizations. St. Petersburg; Moscow: Prosveshchenie.

Kovaleva, G. S., Roslova, L. O., Krasnyanskaya, K. A., \& Rydze, O. A. (2020d). Mathematical literacy: a collection of reference tasks: a textbook for general education organizations. St. Petersburg; Moscow: Prosveshchenie.

Kovaleva, G. S., Rutkovskaya, E. L., \& Polovnikova, A. V. (2020e). Financial literacy: a collection of reference tasks: a textbook for general education organizations. St. Petersburg; Moscow: Prosveshchenie.

Kovaleva, G. S., Ryabinina, L. A., Sidorova, G. A., Chaban, T. Yu. (2020f). Reading's literacy: a collection of reference tasks: a textbook for general education organizations, in two parts, Part 1. St. Petersburg; Moscow: Prosveshchenie.

Krasnov, S. I., Kopoteva, G. L., Logvinova, I. M., Malysheva, N. V., \& Molodykh, E. N. (2019). Methodological design of consciousness discourse for subjects of education. In: The European Proceedings of Social \& Behavioural Sciences. International Conference "Education Environment for the Information Age" (EEIA 2019), June 4-5, 2019, Moscow, Russia. Future Academy, pp. 467-475. https://doi.org/10.15405/epsbs.2019.09.02.54

Law, K. M. Y., Geng, Sh., \& Tongmao, L. (2019). Student enrollment, motivation and learning performance in a blended learning environment: The mediating effects of social, teaching, and cognitive presence. Computers \& Education, 136, 1-12. https://doi.org/10.1016/i.compedu.2019.02.021

Legault, L. (2017). Self-Determination Theory. In: Zeigler-Hill, V., Shackelford, T. (Eds.). Encyclopedia of Personality and Individual Differences. Cham: Springer, pp. 60-76. https://doi.org/10.1007/978-3-319-28099-8 1162-1

Low, R., \& Jin, P. (2009). Motivation and multimedia learning. In: Zheng, R. Z. (Ed.). Cognitive Effects of Multimedia Learning, 3rd ed. IGI Global, pp. 154-172. https://doi.org/10.4018/978-1-60566-158-2.ch009

Ministry of Education of the Russian Federation. (2019). Consolidated reports in form No. OO-1 "Information on the organization providing training in educational programs of primary general, basic general, secondary general 
education" at the beginning of the 2018/2019 academic year in the Russian Federation. Available:

https://docs.edu.gov.ru/document/d5347c330ed0f2f685a4ef5190454611/

Novikov, A. M. (2011). Development of the student's 'self' (categorical aspect of the problem). Higher education in Russia, 11, 130-136.

Novikov, A. M., \& Novikov, D. A. (2009). Project as a cycle of innovative activity and organization of practical educational activities. Innovative projects and programs in education, 5, 3-11.

OECD. (n.d). International coordination center. Available: http://www.oecd.org/

OECD. (2019). PISA 2018 Assessment and Analytical Framework. Paris: OECD Publishing. https://doi.org/10.1787/b25efab8-en

Orlova, S. L., Taslitskaya, E. M., \& Chetvertnykh, T. V. (2019). Possibilities of examination of tasks for evaluating the students' functional literacy in the system of teachers' additional professional education. Domestic and foreign pedagogy, 4(61), 248-257.

Osmolovskaya, I. M., Ivanova, E. O., Klarin, M. V., Serikov, V. V., \& Aliev, Yu. B. (2019). Innovative educational practices: classification, design, modeling. In: The European Proceedings of Social \& Behavioural Sciences. International Conference "Education Environment for the Information Age" (EEIA 2019), June 4-5, 2019, Moscow, Russia. Future Academy, pp. 598-605. https://doi.org/10.15405/epsbs.2019.09.02.68

Panarina, L. Yu., Sorokina, I. V., Smagina, O. A., \& Zaitseva, E. A., eds. (2019). Development of primary school students' functional literacy: a methodological guide for teachers. Samara: Samara Institute of advanced training and retraining of education workers.

Pentin, A. Yu. (2010). We failed in PISA again. Municipal education: innovations and experiment, 6, 11-16.

Pentin, A. Yu., Kovaleva, G. S., Davidova, E. I., \& Smirnova, E. S. (2018). Science education state in Russia according to the results of the TIMSS and PISA international studies. Educational Studies, 1, 79-100.

https://doi.org/10.17323/1814-9545-2018-1-79-109

Pluzhnikova, N. N., Korableva, E. V., \& Bokova, T. N. (2018). Intelligence and technology: the problem of interaction. Espacios, 39(38), 20.

Roslova, L. O., Krasnianskaya, K. A., \& Kvitko, E. S. (2019). Conceptual bases of formation and evaluation of mathematical literacy. Domestic and foreign pedagogy, 4(61), 58-79.

Rudik, G. A., Zhaytapova, A. A., \& Stog, S. G. (2014). Functional literacy - the imperative of time. Education through life: continuous education for sustainable development, 1(12), 263-269.

Sabieva, K. U., \& Bulatova, B. S. (2017). On some aspects of teachers' professional competence development in the formation of students' functional literacy. Modern trends in the development of science and technology, 1(8), 120125.

Savchenkov, A. V. (2019). Aspects of formation of teachers professional stability. In: The European Proceedings of Social \& Behavioural Sciences. International Conference "Education Environment for the Information Age" (EEIA 2019), June 4-5, 2019, Moscow, Russia. Future Academy, pp. 702-710. https://doi.org/10.15405/epsbs.2019.09.02.80

Sergeeva, M. G., Bedenko, N. N., \& Machekhina, O. N. (2017). Scientific bases of individual socialization in the conditions of globalization and informatization of society. Moscow: Peoples' Friendship University of Russia (RUDN).

Sergeeva, T. F. (2020). Mathematics for every day. Grades 6-8: textbook for general education organizations. Moscow: Prosveshchenie.

Sergis, S. (2018). Investigating the impact of Flipped Classroom on students' learning experiences: A Self-

Determination Theory approach. Computers in Human Behavior, 78, 368-378.

https://doi.org/10.1016/i.chb.2017.08.011

Shaikhelislamov, R. F. (2019). To get into the top ten: readiness of regions to implement tasks related to the formation of functional literacy. Domestic and foreign pedagogy, 4(61), 218-235.

Silva, L. R., Santos, A. R., \& Santos, I. T. R. (2020). Public policies for education of/in the field and the school environment in a settlement of the MST: the intimate relationship with the pedagogical policy. Journal of Research and Knowledge Spreading, 1(1), e11737. http://dx.doi.org/10.20952/jrks1111737

Slavin, R. E. (2011). Instruction Based on Cooperative Learning. In: Mayer, R. E., Alexander, P. A. (Eds.). Handbook of Research on Learning and Instruction. New York: Routledge, pp. 344-360. 
Sukhodimtseva, A. P., Sergeeva, M. G., Donskaya, M. V., Kupriyanova, M. E., \& Tomashevich, S. B. (2018a). Metadisciplinarity in education: solving actual problems. Espacios, 39(2), 27.

Sukhodimtseva, A. P., Sergeeva, M. G., \& Sokolova, N. L. (2018b). Interdisciplinarity in school education: historical aspect and implementation strategies in the present. Nauchnyy dialog, 3, 319-336. https://doi.org/10.24224/2227$\underline{1295-2018-3-319-336}$

Sukhodimtseva, A. P., Vorozheikina, N. I., \& Eremina, Yu. B. (2020). Integration approach to solving problems of interdisciplinary nature in the conditions of post-industrial education. Smart Innovation, Systems and Technologies, 138, 501-510. https://doi.org/10.24224/2227-1295-2018-3-319-336

TALIS. (2018). The second part of the TALIS national report Federal Institution for the Assessment of the Quality Education. Available: https://fioco.ru/Talis-18-results-2

Teacher of the Year. (2018). Alikhan Dinayev's (the winner's) lesson. Available: https://www.youtube.com/watch?v=uwa26zH7Vwo\&t=2396s

Van Doorn, G., \& Eklund, A. (2013). Face to Facebook: Social media and the learning and teaching potential of symmetrical, synchronous communication. Journal of University Teaching \& Learning Practice, 10(1), 1-16. Available: https://files.eric.ed.gov/fulltext/EJ1005279.pdf

Varkulevich, T. V., Shumik, E. G., \& Baturina, O. A. (2018). Strategic partnership of universities as a tool of territorial development dynamics: regional aspect. Espacios, 39(2), 31-39.

Volkova, S. A., Petrova, N. N., \& Solodukhina, N. N. (2019). Training of natural science teachers as part of lifelong learning. In: The European Proceedings of Social \& Behavioural Sciences. International Conference "Education Environment for the Information Age" (EEIA 2019), June 4-5, 2019, Moscow, Russia. Future Academy, pp. $986-991$. https://doi.org/10.15405/epsbs.2019.09.02.111

Woodside, A. (2010). Case Study Research: Theory, Methods and Practice. Emerald Group Publishing.

Yilmaz, R. (2017). Exploring the role of e-learning readiness on student satisfaction and motivation in flipped classroom. Computers in Human Behavior, 70, 251-260. https://doi.org/10.1016/i.chb.2016.12.085

Received: 31 January 2021 | Accepted: 2 April 2021 | Published: 25 April 2021

This is an Open Access article distributed under the terms of the Creative Commons Attribution License, which permits unrestricted use, distribution, and reproduction in any medium, provided the original work is properly cited. 